\title{
Expression of CTGF and Cyr61 in colorectal cancer
}

\author{
Rahul Ladwa, ${ }^{1}$ Howard Pringle, ${ }^{1}$ Rohan Kumar, ${ }^{1}$ Kevin West ${ }^{2}$
}

${ }^{1}$ Department of Cancer Studies and Molecular Medicine, Infirmary Close, University of Leicester, Robert Kilpatrick Clinical Sciences Building, Leicester Royal Infirmary, Leicester, UK

2Department of Pathology, Infirmary Close, Leicester Royal Infirmary, Leicester, UK

Correspondence to Dr Rahul Ladwa, 54 Carty Road, Leicester LE5 10S, UK; rl57@hotmail.co.uk

Accepted 7 October 2010 Published Online First 15 November 2010

\section{ABSTRACT}

Background The CCN genes encode secreted extracellular matrix proteins cysteine rich-61 (Cyr61), connective tissue growth factor (CTGF) and nephroblastoma overexpressed (Nov). They are involved in diverse cellular functions. Expression of these factors in tumours has produced conflicting results. More recently, research has focused on molecular biomarkers to indicate progression of a disease or the susceptibility of the disease to a given treatment.

Aims The purpose of this study was to determine the expression of CTGF and Cyr61 genes and proteins in colorectal cancer. Expression was compared with various clinicopathological parameters including Dukes' stage and TNM stage. We determined the in vitro effects of hypoxia on Cyr61 and CTGF expression in colorectal cancer cell lines.

Results Hypoxia significantly reduced CTGF mRNA expression $(p<0.01)$ in HT29 and Caco-2 cell lines. Cyr61 was induced $(p<0.01)$ in HT29 cell lines but significantly reduced $(p<0.01)$ in Caco-2 cell lines under hypoxic conditions. High levels of CTGF and Cyr61 mRNA were found in colorectal cancer compared with normal colon $(p<0.05)$. Expression was reduced in more advanced cancers (Dukes' C vs Dukes' A and B). There was a significant association between CTGF protein expression and advancing Dukes' stage $(p<0.01)$, T stage $(p<0.01)$ and lymph-node involvement $(p<0.05)$, but there was no significant association between Cyr61 expression and clinicopathological parameters.

Conclusion Upregulation of Cyr61 and CTGF gene expression in colorectal cancer suggests they have a role in tumour initiation or development. However, the genes are not as highly expressed in advanced stages of colorectal cancer, suggesting their role may be important at an early stage of tumour development. These genes maybe used as early biomarkers to risk-stratify patients. Hypoxia alters the expression of these genes in colorectal cancer cell lines. Further studies are needed to determine whether targeting these genes would be useful in future therapy.

\section{INTRODUCTION}

Colorectal cancer is one of the commonest malignant neoplasm worldwide, and over 35000 colorectal cancers were diagnosed in England in 2004. ${ }^{1}$ Unfortunately, over $57 \%$ have regional or distant spread of their disease at the time of diagnosis. ${ }^{2}$ More recently, research has focused on molecular biomarkers to indicate progression of a disease or the susceptibility of the disease to a given treatment. ${ }^{3}$

The CCN family comprises cysteine rich-61 (Cyr61/CCN1), connective tissue growth factor (CTGF/CCN2) and nephroblastoma overexpressed (Nov/CCN3). These proteins stimulate mitosis, adhesion, apoptosis, extracellular matrix production, growth arrest and migration of multiple cell types. ${ }^{4}$ The role of the CCN members in cancer is far from clear, and the results in the literature remain controversial.

To date, the expression of CTGF and Cyr61 mRNA and protein has not been studied together in colorectal cancer specimens. In this study, we determined the in vitro effects of hypoxia on Cyr61 and CTGF expression in colorectal cancer cell lines. We assessed the expression of Cyr61 and CTGF mRNA and protein in colorectal cancer. This was compared with various clinicopathological parameters.

\section{MATERIALS AND METHODS}

Ethical permission was sought to allow the use of patient tissue samples for the purpose of this study that included 39 patients who had a primary colorectal tumour (table 1).

\section{Cell culture}

HT29 and Caco-2 cells derived from a human colorectal cancer were cultured in McCoy's 5A Medium (Invitrogen, Carlsbad, California) supplemented with $10 \%$ fetal bovine serum and incubated in $5 \%$ carbon dioxide. To induce hypoxia, cells were treated with $100 \mu \mathrm{M}$ of desferrioxamine (Sigma, St Louis, Missouri). Caco-2 cells were treated with desferrioxamine for 24 and $48 \mathrm{~h}$. Normoxic cell lines were cultured in the same way without the use of desferioxamine.

\section{RNA isolation and RT-PCR}

Isolation of mRNA and reverse transcription was carried according to the manufacturer's instructions. ${ }^{5}$ Briefly, a $10 \mu$ laliquot of mRNA was reversetranscribed into single-stranded cDNA using Avian Myeloblastosis Virus Reverse Transcriptase (AMVRT) and random hexamers (Promega, Madison, Wisconsin). Samples were subsequently incubated at $42^{\circ} \mathrm{C}$ for $60 \mathrm{~min}$. The cDNA $(1 \mu \mathrm{l})$ was amplified with the forward $(\mathrm{F})$ and reverse $(\mathrm{R})$ primers by PCR. Thermal cycling conditions were as follows: one cycle of $98^{\circ} \mathrm{C}$ for $3 \mathrm{~min}, 60^{\circ} \mathrm{C}$ for $3 \mathrm{~min}$ and $72^{\circ} \mathrm{C}$ for $1 \mathrm{~min}$ and 40 cycles of $94^{\circ} \mathrm{C}$ for $30 \mathrm{~s}$, $60^{\circ} \mathrm{C}$ for $30 \mathrm{~s}$ and $72^{\circ} \mathrm{C}$ for $30 \mathrm{~s}$. At the initial annealing phase, thermostable Taq DNA polymerase (Promega) was added to each PCR reaction. PCR-amplification products were loaded onto a $3 \%$ agarose gel containing $50 \mu \mathrm{g} / 100 \mathrm{ml}$ ethidium bromide. The primers used for RT-PCR are outlined in table 2.

\section{Real-time quantitative PCR}

Briefly $4 \mu \mathrm{l}$ of cDNA was amplified in a $6 \mu \mathrm{l}$ reaction solution containing, $5 \mu \mathrm{l}$ of SYBR Green Jumpstart Taq Ready Mix, $0.2 \mu \mathrm{l}$ of both the forward and reverse primer and $0.6 \mu \mathrm{l}$ of sterile $\mathrm{H}_{2} \mathrm{O}$. Thermal cycling conditions were as follows: one cycle of 
Table 1 Clinicopathological characteristics of the study population

\begin{tabular}{lr}
\hline Clinicopathological parameters & N \\
\hline Gender & \\
Male & 24 \\
Female & 15 \\
Dukes' stage & \\
A & 10 \\
B & 11 \\
C & 18 \\
T staging & \\
1 & 5 \\
2 & 6 \\
3 & 16 \\
4 & 12 \\
Node status & \\
0 & 21 \\
1 & 9 \\
2 & 9 \\
Tumour differentiation & \\
Well & 6 \\
Moderate & 25 \\
Poor & 8 \\
Extramural vascular invasion & \\
No & 30 \\
Yes & 9 \\
\hline &
\end{tabular}

Table 2 Primer sequences used for this study

\begin{tabular}{|c|c|}
\hline Gene & Sequence $\left(5^{\prime}-3^{\prime}\right)$ \\
\hline \multirow[t]{2}{*}{ Cyr61 } & F: CCTTGTGGACAGCCAGTGTA \\
\hline & R: TGTAGAAGGGAAACGCTGCT \\
\hline \multirow[t]{2}{*}{ CTGF } & F: CCTGGTCCAGACCACAGAGT \\
\hline & R: GTAATGGCAGGCACAGGTCT \\
\hline \multirow{2}{*}{$\begin{array}{l}\text { Glyceraldehyde-3-phosphate } \\
\text { dehydrogenase }\end{array}$} & F: CAAGAGCACAAGAGGAAGA \\
\hline & R: ACTGTGAGGAGGGGAGATTC \\
\hline $18 \mathrm{~s} F$ & GCT GAG AAG ACG GTC GAA CT \\
\hline CTGF F & CCA AAA GTT ACA TGT TTG CAC CT \\
\hline Cyr61 F & GGA GGG AGG GGA AAT GTA AT \\
\hline Universal reverse primer & CAC AAC GAG ACG ACG ACA AC \\
\hline \multicolumn{2}{|c|}{$\begin{array}{l}\text { Cysteine rich-61 (Cyr61), connective tissue growth factor (CTGF) and glyceraldehyde-3- } \\
\text { phosphate dehydrogenase primer sets were used in the in vitro analysis of hypoxic } \\
\text { induction of the CCN genes. } \\
\text { Primer sequences } 18 \mathrm{~s} F, C T G F F \text { and Cyr61 F used for quantitative RT-PCR on paraffin- } \\
\text { embedded tissues. The universal reverse transcriptase primer includes the ambiguity codes } \\
V N \text {, where } V \text { is } A, C \text { or } G \text {, and N can be any nucleotide } A, C, G \text { or T. The universal reverse } \\
\text { primer is a common reverse primer for all subsequent PCR reactions. }\end{array}$} \\
\hline
\end{tabular}

$98^{\circ} \mathrm{C}$ for $3 \mathrm{~min}$ and $60^{\circ} \mathrm{C}$ for $5 \mathrm{~min}$ and 40 cycles of $94^{\circ} \mathrm{C}$ for $15 \mathrm{~s}$ and $60^{\circ} \mathrm{C}$ for $30 \mathrm{~s}$. Comparative gene expression was calculated using the Pfaffl equation. ${ }^{6}$

\section{RNA extraction of paraffin-embedded tissues}

The use of formalin-fixed tissues as a source of RNA requires appropriate RNA extraction and amplification methods. ${ }^{7}$ RNA was extracted from paraffin-embedded tissues as follows, using
Figure 1 In vitro analysis of cysteine rich-61 (Cyr61) and connective tissue growth factor (CTGF) mRNA in colorectal cancer cell lines exposed to hypoxia at 24 and $48 \mathrm{~h}$. (A) RT-PCR analysis of Cyr61 and CTGF expression in HT29 and Caco-2 colorectal cancer cell lines in normoxic and hypoxic $(\mathrm{H})$ conditions. Control cultures were kept under normoxia (N). Glyceraldehyde-3phosphate dehydrogenase bands are shown to confirm equal loading of RNA. (B) Log relative quantification of Cyr61 and CTGF in the HT29 and Caco2 colorectal cancer cell lines using desferrioxamine-induced hypoxia $(\mathrm{H})$ referenced to each cell line's normoxic (N) control by qRT-PCR (40 cycles). The Caco-2 cell lines were exposed to desferrioxamine-induced hypoxia for 24 and $48 \mathrm{~h}$. Error bars represent the SE of the results due to variation in triplicate results. ${ }^{*} p<0.05 ;{ }^{* *} p<0.01$.
A

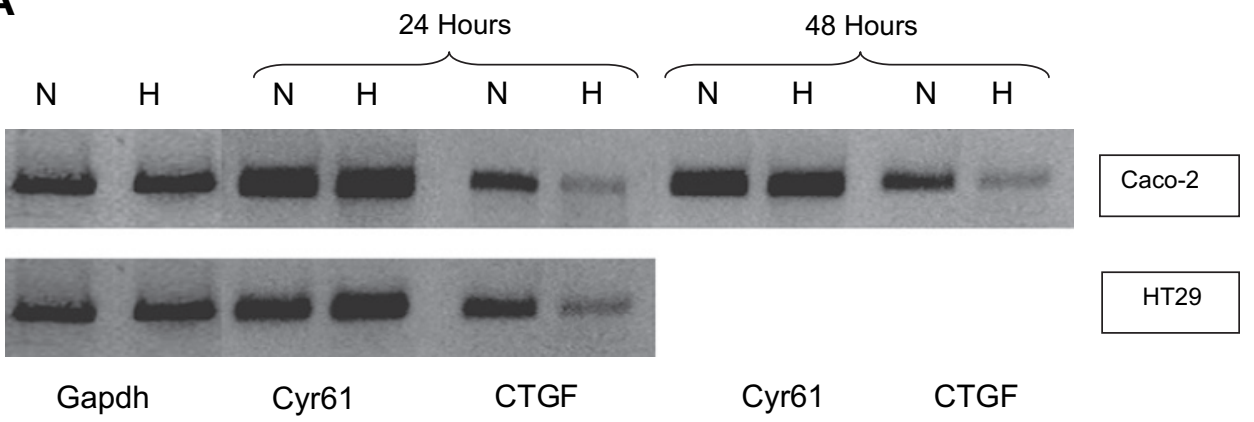

B

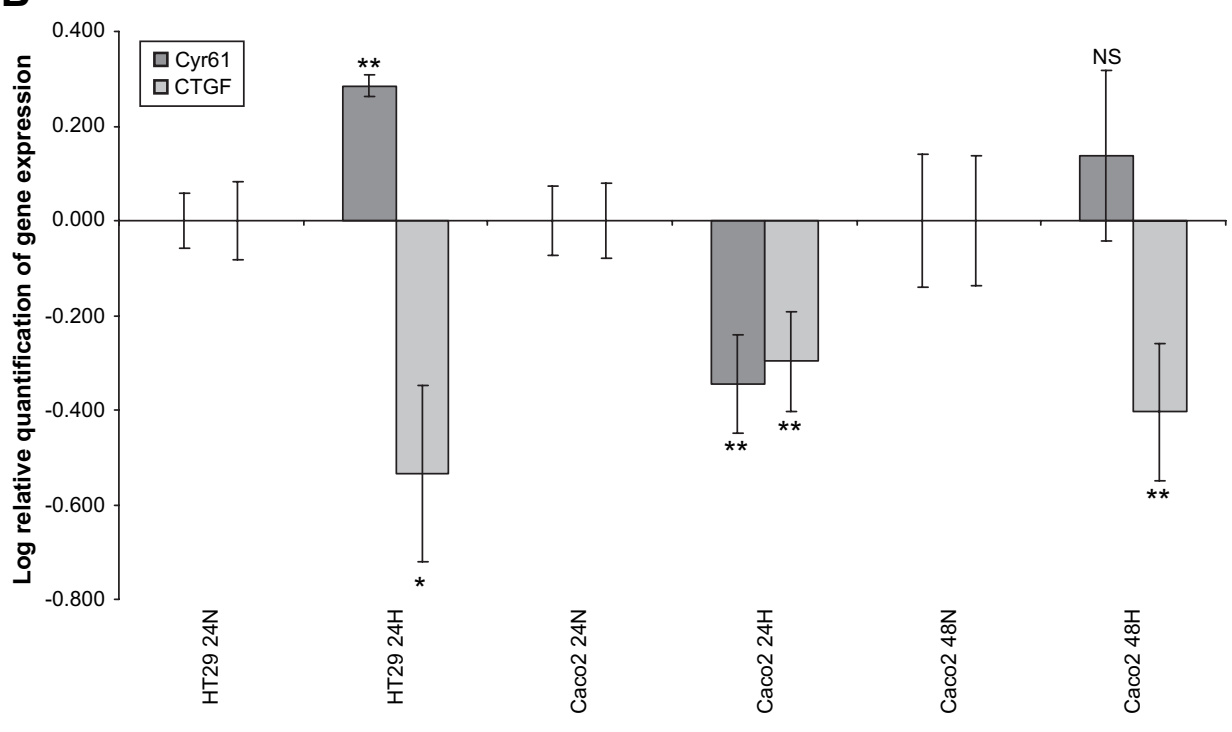


Figure 2 Log relative quantification $(\log R 0)$ of cysteine rich-61 (Cyr61) and connective tissue growth factor (CTGF) mRNA expression in colorectal cancer paraffin embedded tissues $(\mathrm{N}=28)$ and histologically normal bowel from patients with colorectal cancer $(\mathrm{N}=7)$ by qRT-PCR. Cases $(1-28)$ are referenced to $\mathrm{N} 2$.

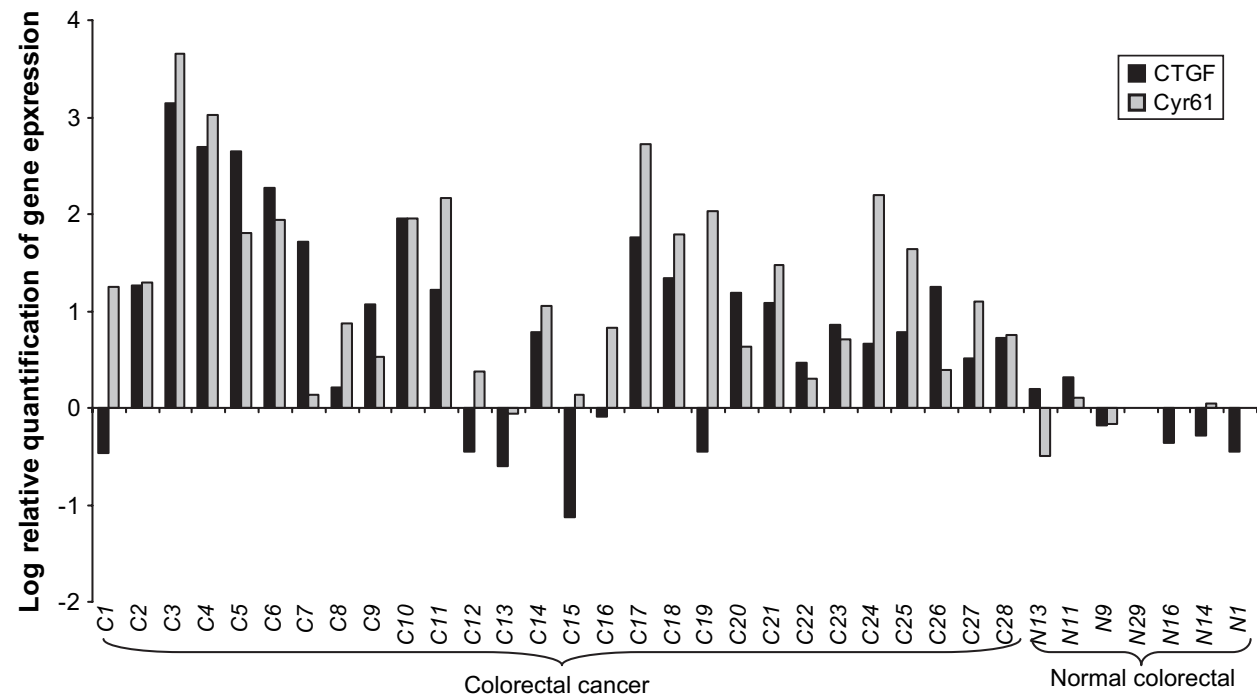

$500 \mu \mathrm{l} 0.1 \%$ sodium dodecyl sulfate $(\mathrm{pH} 7.3)$ and $\mathrm{Tris} / \mathrm{HCl}(\mathrm{pH}$ 8.0). This was then kept overnight in $5 \mu$ l of proteinase $\mathrm{K}$ (Sigma) $(1 \mu \mathrm{g} / \mathrm{ml})$ at $65^{\circ} \mathrm{C}$. Total RNA was extracted using TRIzol reagent (Invitrogen) according to the manufacturer's protocol.

A universal reverse transcriptase primer (URTP) was designed that targets the 3 ' poly (A) tail of mRNA and adds a unique tag sequence not otherwise found in the human genome. The RNA $(10 \mu \mathrm{l})$ was added to $1.5 \mu \mathrm{l}$ of CTGF URTP, $1.5 \mu \mathrm{l}$ of $18 \mathrm{~S}$ URTP and $2 \mu$ of sterile water. This was heated to $70^{\circ} \mathrm{C}$ for $5 \mathrm{~min}$ and then reverse-transcribed as stated before.

Real-time PCR was subsequently performed using a specific forward (F) primer and a universal reverse primer that binds to the universal reverse transcriptase tag primer (table 2). This priming method has the advantage of being sensitive and specific. $^{8}$

\section{Immunohistochemistry}

For immunostaining, tissue sections were subjected to a heatmediated antigen retrieval procedure using $0.01 \mathrm{M}$ citrate buffer. Polyclonal antibody preparations specific for CTGF (ab-6992; Abcam, Cambridge, UK) and CYR61 (sc-13100; Santa Cruz Biotechnologies, Santa Cruz, California) were used. ${ }^{9}{ }^{10}$ CTGF antibody was applied to the slides at a dilution of 1:1000, while Cyr61 antibody was used at a dilution of 1:2000. A secondary biotinylated swine antirabbit antibody (Dako, Carpintería, California) was used at a dilution of 1:800 with strepavidin-biotin alkaline phosphatase (Dako) complex. Slides were stained with fast red substrate.

Cyr61 immunostaining was determined by the $\mathrm{H}$ score calculated for both the tumour cell and extracellular matrix expression combined. ${ }^{11}$ A score was devised to assign absent, weak, moderate and strong staining intensity to CTGF.

\section{Statistical analysis}

Statistical analysis of cell lines using qRT-PCR was based on Student $t$ tests. Comparisons between groups were made by a one-way analysis of variance (ANOVA) using Bonferroni corrections. Differences between immunohistochemistry data were detected using Mann-Whitney and Kruskal-Wallis tests. A trend analysis was performed using the Jonckheere-Terpstra test.

\section{RESULTS}

In vitro effects of hypoxia on mRNA expression of Cyr61 and CTGF in colorectal cancer cell lines

CTGF mRNA expression consistently decreased in HT29 and Caco-2 cell lines when exposed to desferrioxamine $(p<0.01)$. CTGF was downregulated at both 24 and $48 \mathrm{~h}$ induction of hypoxia in Caco-2 cell lines. Further downregulation of CTGF was observed at $48 \mathrm{~h}$ compared with $24 \mathrm{~h}$. Cyr61 was upregulated in the HT29 cell line $(\mathrm{p}<0.01)$ but downregulated in the Caco-2 cell line $(p<0.01)$. Cyr61 mRNA was not significantly different from normoxic conditions at $48 \mathrm{~h}$ of hypoxia in the Caco-2 cell line (figure 1).

Table 3 Association of cysteine rich-61 (Cyr61) and connective tissue growth factor (CTGF) mRNA expression with clinicopathological parameters in colorectal cancer, as determined by qRT-PCR

\begin{tabular}{|c|c|c|c|c|c|}
\hline \multirow{2}{*}{$\begin{array}{l}\text { Clinicopathological } \\
\text { parameters }\end{array}$} & \multirow[b]{2}{*}{$\mathbf{N}$} & \multicolumn{2}{|l|}{ CTGF mRNA } & \multicolumn{2}{|l|}{ Cyr61 mRNA } \\
\hline & & Mean ( \pm SD) & p Value & Mean ( \pm SD) & p Value \\
\hline \multicolumn{6}{|l|}{ Dukes' stage } \\
\hline Normal & 7 & $-0.111(0.289)$ & $0.008^{*} \dagger$ & $-0.103(0.246)$ & $0.009 * \dagger$ \\
\hline$A$ & 7 & $1.346(0.998)$ & $0.029^{*} \neq$ & $1.571(0.917)$ & $0.204 \ddagger$ \\
\hline B & 10 & $1.246(1.096)$ & & $1.473(1.100)$ & \\
\hline C & 11 & $0.410(0.903)$ & & $0.996(0.755)$ & \\
\hline \multicolumn{6}{|l|}{ T stage } \\
\hline 1 & 4 & $1.634(0.702)$ & $0.575 \dagger$ & $1.626(1.096)$ & $0.812 \dagger$ \\
\hline 2 & 3 & $0.964(1.366)$ & & $1.498(0.842)$ & \\
\hline 3 & 11 & $0.858(1.267)$ & & $1.122(1.113)$ & \\
\hline 4 & 10 & $0.754(0.852)$ & & $1.334(0.759)$ & \\
\hline \multicolumn{6}{|l|}{ Node status } \\
\hline 0 & 17 & $1.288(1.026)$ & $0.300 \dagger$ & $1.514(0.999)$ & $0.116 \dagger$ \\
\hline 1 & 6 & $0.822(0.854)$ & & $1.377(0.799)$ & \\
\hline 2 & 5 & $-0.083(0.752)$ & & $0.539(0.386)$ & \\
\hline \multicolumn{6}{|l|}{ Tumour differentiation } \\
\hline Well & 6 & $1.045(1.102)$ & $0.832 \dagger$ & $1.394(1.105)$ & $0.763 \dagger$ \\
\hline Moderate & 16 & $0.993(1.062)$ & & $1.375(0.953)$ & \\
\hline Poor & 6 & $0.707(1.155)$ & & $1.053(0.806)$ & \\
\hline \multicolumn{6}{|c|}{ Extramural vascular invasion } \\
\hline No & 22 & $1.019(1.033)$ & $0.474 \dagger$ & $1.384(0.891)$ & $0.433 \dagger$ \\
\hline Yes & 6 & $0.663(1.191)$ & & $1.039(1.118)$ & \\
\hline
\end{tabular}

Mean mRNA expression values and SD are included for each factor studied.

*Statistical significance is when $\mathrm{p}<0.05$

tOne-way ANOVA test.

‡Jonckheere-Terpstra Test was performed on Dukes' stage A, B and C tumours only. 
Figure 3 Log relative quantification of cysteine rich-61 (Cyr61) and connective tissue growth factor (CTGF) mRNA expression with Dukes' stage in colorectal cancer paraffin embedded tissues and normal colorectal tissues. ${ }^{*} \mathrm{p}<0.05$. NS, not significant.

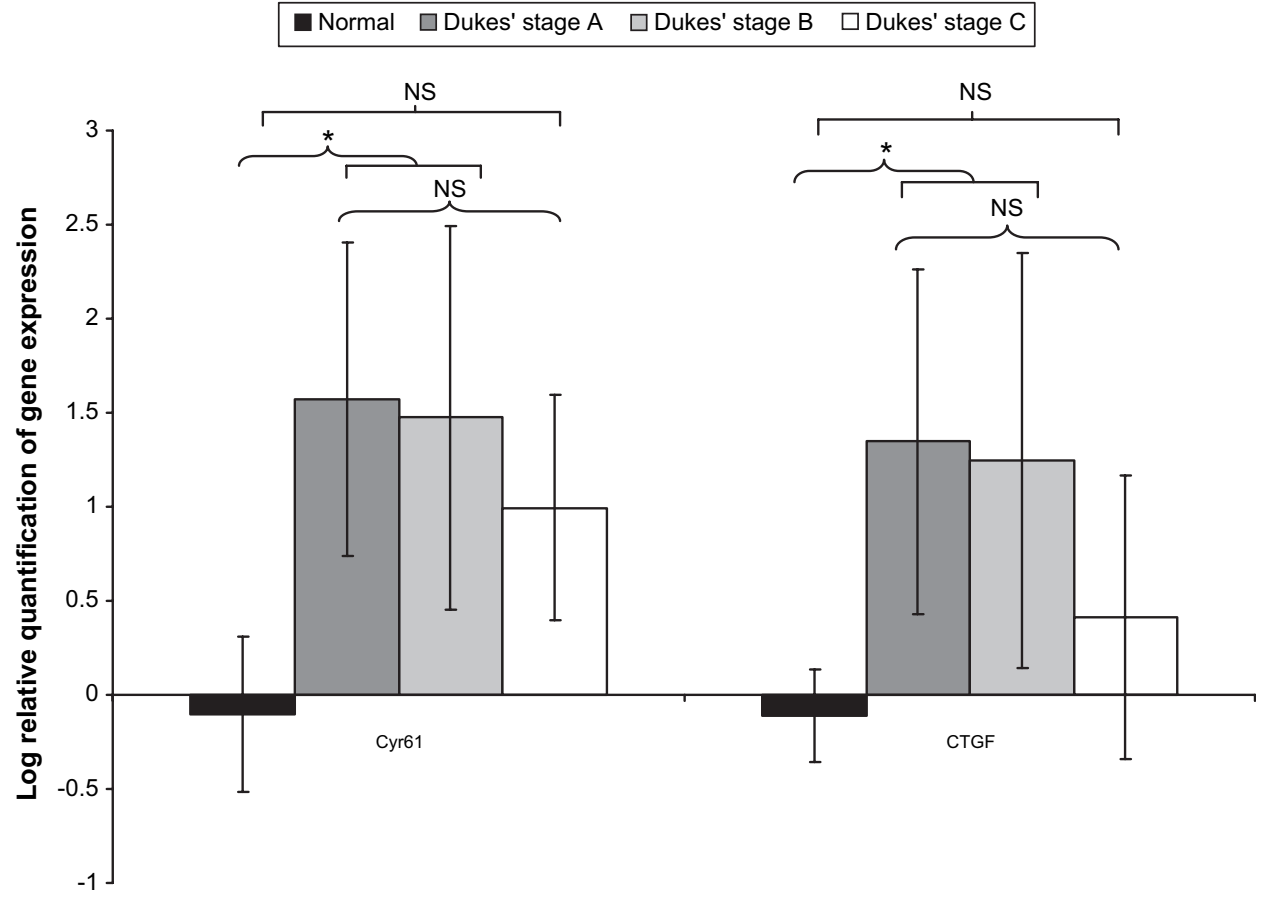

\section{Expression of CTGF and Cyr61 mRNA in colorectal cancer tissues}

CTGF and Cyr61 mRNA were all readily detectable in all tumour tissue samples and control mucosa specimens (figure 2). CTGF and Cyr61 mRNA was expressed to a greater degree in the majority of colorectal cancer specimens (table 3 ) compared with normal colon tissue $(p<0.01)$. This was particular evident in Dukes' stage A and B tumours. There was no significant difference between CTGF and Cyr61 mRNA expression between Dukes' stage $\mathrm{C}$ tumours and normal colon tissue. However, there was no statistically significant difference in CTGF and Cyr61 mRNA with advancing Dukes' stage (figure 3).

We did not identify any statistically significant difference between CTGF and Cyr61 mRNA expression with other
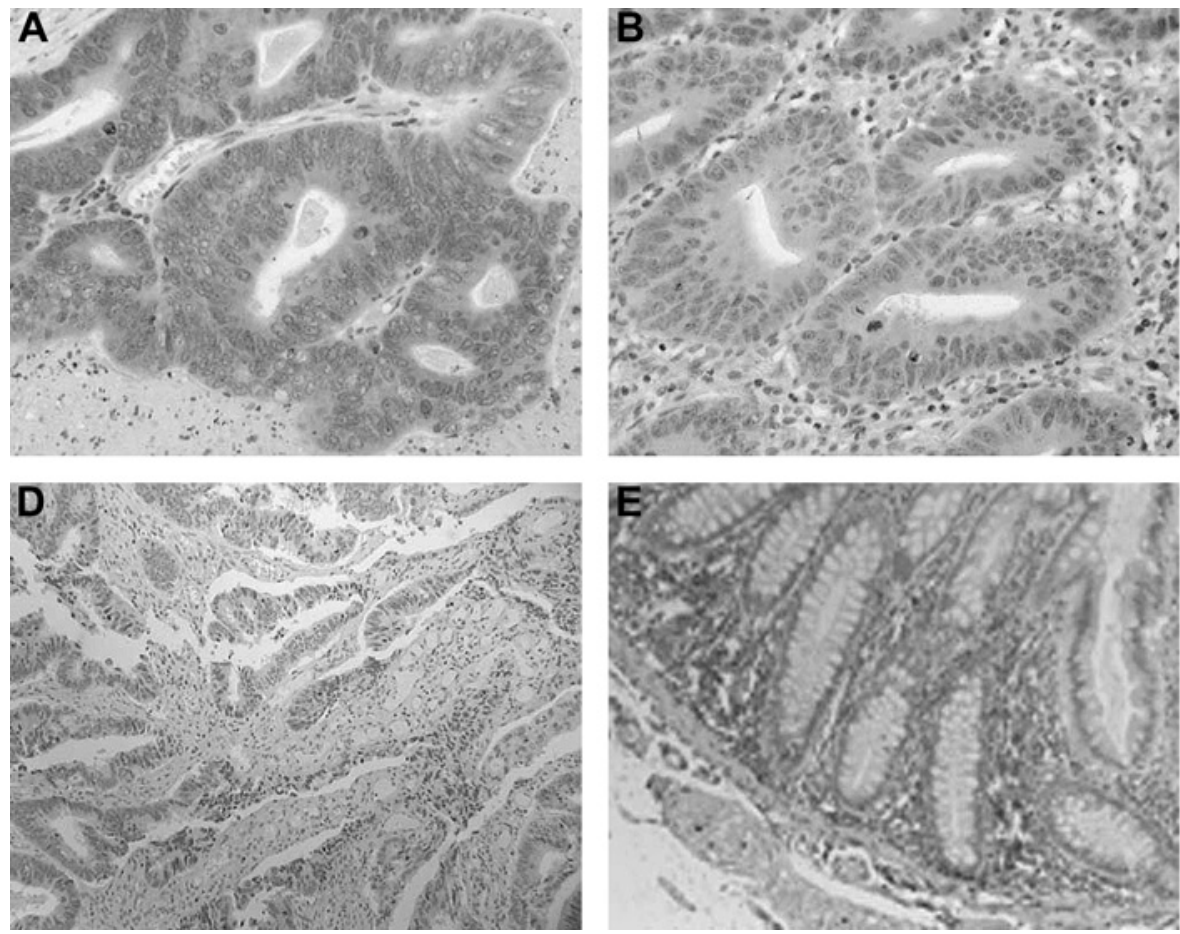
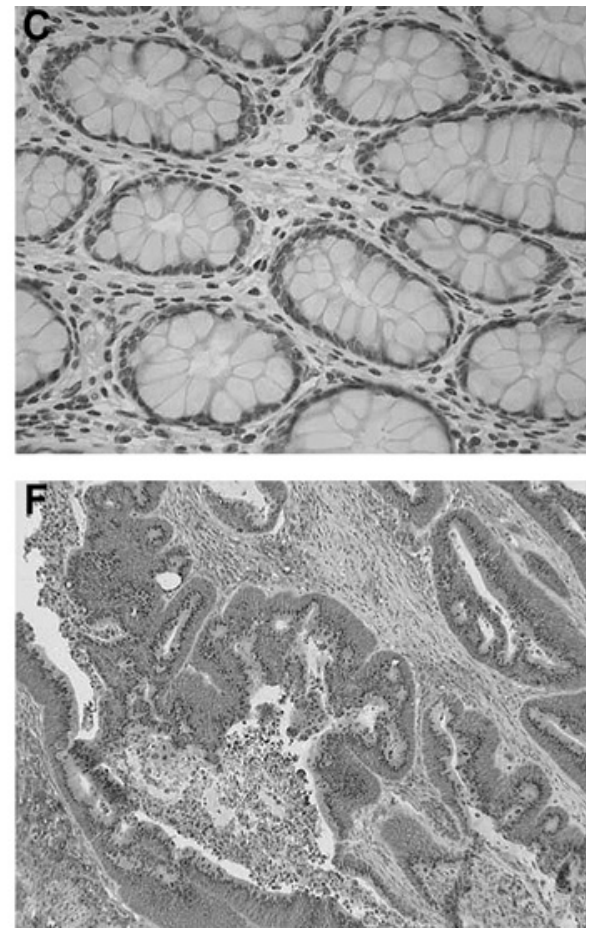

Figure 4 Connective tissue growth factor immunostaining in colorectal cancer tissue showing diffuse cytoplasmic staining of different grades of intensity: (A) strong cytoplasmic staining; (B) moderate cytoplasmic staining; (C) limited staining of normal colorectal tissue; (D) control sections of colorectal cancer with no primary antibody. Cysteine rich-61 showed $(\mathrm{E})$ prominent staining in the lamina propria of normal colorectal tissue and $(\mathrm{F})$ strong tumour staining. 
pathological parameters such as TNM stage, tumour differentiation or extramural vascular invasion.

\section{Expression of CTGF and Cyr61 protein levels in colorectal cancer tissues}

Immunohistochemistry was performed on 39 cases for CTGF and 28 cases for Cyr61 (11 cases were omitted because of a lack of tissue).

CTGF protein expression was present in $95 \%$ of cases. Tumour tissues showed varying intensities of staining, with the most prominent staining in the cytoplasm of tumour cells (figure 4). There was an increase in the intensity of staining in advancing Dukes' stage, tumour stage and node stage (table 4). Protein expression was higher in Dukes' stage C compared with Dukes' stage A $(p<0.01)$. There was no significant difference between Dukes' stages A or C tumours compared with Dukes' stage B tumours (figure $5 \mathrm{~A})$. Also, there was an increase $(\mathrm{p}<0.01)$ in CTGF protein expression in pT3 and pT4 staged tumours compared with pT1 and pT2 tumours (figure $5 \mathrm{~B}$ ). There was a significant increase $(p<0.01)$ in expression of CTGF protein in tumours staged as $\mathrm{pN} 1$ and $\mathrm{pN} 2$ compared with $\mathrm{pN} 0$ (figure 5C).

Cyr61 staining was present in $82 \%(23 / 28)$ of cases. Staining was present in both the tumour and extracellular matrix (figure 4). There were no significant differences between Cyr61 protein expression and clinicopathological parameters (table 4).

\section{DISCUSSION}

In the present study, we have studied the expression of mRNA and protein expression in colorectal cancer using qRT-PCR and immunohistochemistry. We have shown for the first time an increased expression of CTGF and Cyr61 genes and protein in colorectal cancer. Expression of CTGF and Cyr61 has led to conflicting roles in a variety of cancers. Overexpression of CTGF,

Table 4 Association of connective tissue growth factor (CTGF) and cysteine rich-61 (Cyr61) protein levels with clinicopathological parameters in colorectal cancer cases

\begin{tabular}{|c|c|c|c|c|c|c|}
\hline \multirow{2}{*}{$\begin{array}{l}\text { Clinicopathological } \\
\text { parameters }\end{array}$} & \multicolumn{3}{|c|}{ Intensity of CTGF staining } & \multicolumn{3}{|c|}{ Cyr61 staining } \\
\hline & $\overline{\mathbf{N}}$ & Mean ( \pm SD) & p Value & $\overline{\mathbf{N}}$ & Mean ( \pm SD) & p Value \\
\hline \multicolumn{7}{|l|}{ Dukes' stage } \\
\hline$A$ & 10 & $1.200(0.919)$ & $0.006^{*} \dagger$ & 10 & $1.800(0.919)$ & $0.243 \dagger$ \\
\hline$B$ & 11 & $1.818(0.982)$ & $0.002 \S$ & 5 & $2.800(1.304)$ & $0.226 \S$ \\
\hline C & 18 & $2.388(0.607)$ & & 13 & $2.461(1.266)$ & \\
\hline \multicolumn{7}{|l|}{ T stage } \\
\hline 1 and 2 & 11 & $1.273(0.905)$ & $0.009^{*} \ddagger$ & 10 & $1.800(0.919)$ & $0.133 \ddagger$ \\
\hline 3 and 4 & 28 & $2.179(0.819)$ & & 18 & $2.556(1.247)$ & \\
\hline \multicolumn{7}{|l|}{ Node status } \\
\hline 0 & 21 & $1.524(0.981)$ & $0.004^{*} \neq$ & 15 & $2.133(1.125)$ & $0.473 \neq$ \\
\hline 1 and 2 & 18 & $2.389(0.608)$ & & 13 & $2.462(1.266)$ & \\
\hline \multicolumn{7}{|l|}{ Tumour differentiation } \\
\hline Well & 6 & $1.667(0.816)$ & $0.630 \dagger$ & 6 & $2.333(0.817)$ & $0.692 \dagger$ \\
\hline Moderate & 25 & $1.920(0.996)$ & $0.360 \S$ & 15 & $2.133(1.246)$ & $0.750 \S$ \\
\hline Poor & 8 & $2.125(0.834)$ & & 7 & $2.571(1.397)$ & \\
\hline \multicolumn{7}{|c|}{ Extramural vascular invasion } \\
\hline No & 30 & $1.833(0.949)$ & $0.285 \dagger$ & 22 & $2.227(1.152)$ & $0.642 \dagger$ \\
\hline Yes & 9 & $2.222(0.833)$ & & 6 & $2.500(1.378)$ & \\
\hline
\end{tabular}

Mean CTGF and Cyr61 protein expression values and SD are included here with clinicopathological parameters.

${ }^{*}$ Statistical significance is when $\mathrm{p}<0.05$.

tKruskal-Wallis test.

$\ddagger$ Mann-Whitney test

§Jonckheere-Terpstra test.
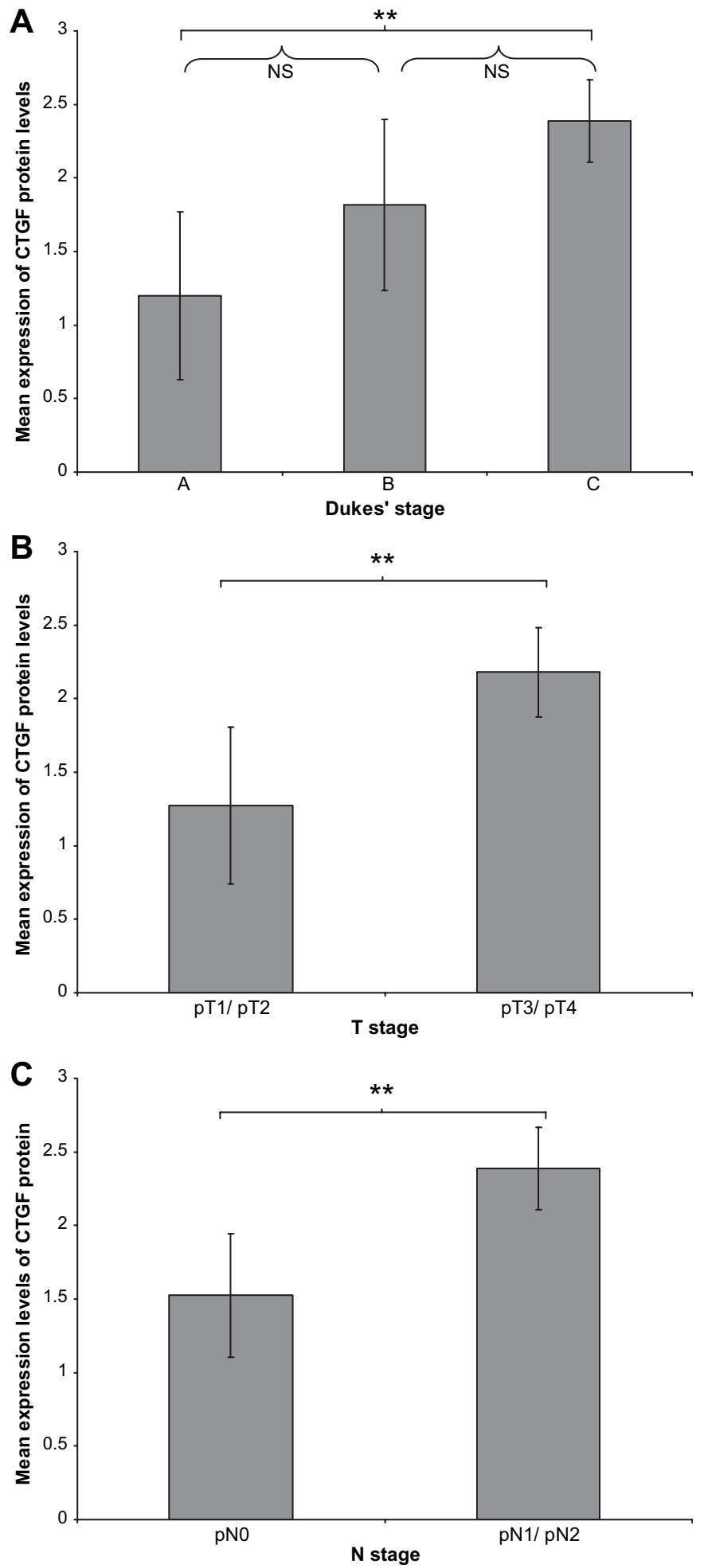

Figure 5 Immunohistochemical expression of connective tissue growth factor (CTGF) protein levels with (A) Dukes' stage (B) tumour (T) stage and (C) Node (N) status in colorectal cancer paraffin embedded tissues. ${ }^{* *} p<0.01$. NS, not significant. Error bars represent $95 \%$ Cls.

compared with normal control specimens, was observed in oesophageal cancer, pancreatic cancer and gliomas. ${ }^{12-14}$ In oesophageal adenocarcinoma and breast cancer, higher levels of CTGF are associated with more advanced disease. ${ }^{12}{ }^{15}$ In contrast, higher levels of CTGF are associated with a better prognosis for lung adenocarcinoma and colorectal cancer. ${ }^{16} 17$ 
Similarly, compared with normal tissues, Cyr61 overexpression was observed in ovarian cancer, breast cancer, gliomas and benign prostate hyperplasia. ${ }^{14}{ }^{18-20}$ In contrast, downregulation was observed in endometrial cancer, thyroid cancer and non-small-cell lung cancer. $^{21-23}$ Furthermore, Cyr61 expression increased in more advanced cases of breast cancer and glioma, suggesting it may have a role in the progression of tumours. ${ }^{14} 24$ Of note, in our study, Cyr61 and CTGF gene expression was overexpression in primary cancers, but its expression was reduced to levels comparable with that of normal colorectal epithelium in advanced Dukes' stage. We did not find a clear link between the level of Cyr61 expression and colorectal cancer progression based on Dukes' stage or TNM stage. In another study, upregulation of Cyr61 expression was present in young patients with early-onset colorectal cancer. ${ }^{25}$ CTGF and Cyr61 could act as early tumour markers that can detect at-risk patients.

Variations in levels of Cyr61 and CTGF could be related to other factors within the tumour microenvironment. Studies have indicated that hypoxia may cause a more aggressive tumour, resistant to treatment. ${ }^{26}$ In this study, we induced hypoxia in colorectal cancer cell lines using desferrioxamine at 24 and $48 \mathrm{~h}$. We showed that CTGF was downregulated in colorectal cancer cell lines when exposed to hypoxia $(p<0.01)$, and further downregulation was noted at $48 \mathrm{~h}$. Hypoxia-mediated downregulation of CTGF could lead to a more invasive tumour. Cyr61 expression varied with cell lines, suggesting a complex mechanism of control. In one study, downregulation of Cyr61 was thought to be associated with more aggressive melanoma cell lines. ${ }^{27}$

We found a correlation between increased protein levels of CTGF with advanced Dukes' stage and TNM stage. In contrast, increased CTGF protein expression in colorectal cancer was related to a better prognostic outcome in another study. ${ }^{28}$ CTGF immunostaining was present in the extracellular matrix but predominantly in the cytoplasm of tumour cells. This is similar to several other tumour types, including oesophageal and pancreatic tumours. ${ }^{12} 13$ We did not quantify CTGF protein staining within the extracellular matrix. The secretion of the peptide into the extracellular matrix could account for differences in this study compared with others and account for differences in the mRNA and protein quantification. One study showed exposure of hypoxia on trophoblasts affected mRNA transcript levels but had no effect on cellular protein levels and, furthermore, increased CTGF protein secretion. ${ }^{29}$

\section{Take-home messages}

- Connective tissue growth factor and cysteine rich-61 play a key role in tumorigenesis in several human malignancies.

- The gene expression of these factors was overexpressed in colorectal cancer but reduced at the advanced Dukes' Stage. Hypoxia alters the expression of these genes in colorectal cancer cell lines.

- We found a correlation between increased protein levels of CTGF with advanced Dukes' stage and TNM stage. The secretion of the peptide into the extracellular matrix could account for differences in the mRNA and protein quantification.

- There was no correlation between Cyr61 and clinical outcomes.
Understanding how CCN proteins function to either promote or inhibit tumorigenesis will require further investigation. Nevertheless, the strong upregulation of CCN expression in colorectal cancer has implicated their role in tumour development and tumour progression. The strong upregulation of these genes early in colorectal cancer suggests that CCN signalling pathways may be useful targets for novel anticancer therapy and could be used to identify colorectal tumours early on in disease progression.

Funding Jean Shanks Foundation.

\section{Competing interests None.}

Ethics approval Ethics approval was provided by the Leicestershire, Northamptonshire and Rutland Research Ethics Committee

Provenance and peer review Not commissioned; externally peer reviewed.

\section{REFERENCES}

1. Office for National Statistics. Cancer statistics - registrations, England, 2004. Series MB1 no. 35. London: Office for National Statistics, 2006.

2. Figueredo A, Coombes ME, Mukherjee S. Adjuvant therapy for completely resected stage II colon cancer. Cochrane Database Syst Rev 2008;(3):CD005390.

3. McHugh SM, O'Donnell J, Gillen P. Genomic and oncoproteomic advances in detection and treatment of colorectal cancer. World J Surg Oncol 2009;7:36.

4. Brigstock DR. The CCN family: a new stimulus package. J Endocrinol 2003;178:169-75.

5. Da Forno PD, Pringle JH, Hutchinson $\mathrm{P}$, et al. WNT5A expression increases during melanoma progression and correlates with outcome. Clin Cancer Res 2008; 14:5825-32.

6. Pfaffl MW. A new mathematical model for relative quantification in real-time RT-PCR. Nucleic Acids Res 2001;29:e45

7. Specht K, Richter T, Muller U, et al. Quantitative gene expression analysis in microdissected archival formalin-fixed and paraffin-embedded tumor tissue. Am J Pathol 2001;158:419-29.

8. Hurteau GJ, Spivack SD. mRNA-specific reverse transcription-polymerase chain reaction from human tissue extracts. Anal Biochem 2002;307:304-15.

9. Ibba-Manneschi L, Manetti M, Milia AF, et al. Severe fibrotic changes and altered expression of angiogenic factors in maternal scleroderma: placental findings. Ann Rheum Dis 2010;69:458-61.

10. Lv H, Fan E, Sun S, et al. Cyr61 is up-regulated in prostate cancer and associated with the p53 gene status. J Cell Biochem 2009:106:738-44.

11. Bacus S, Flowers JL, Press MF, et al. The evaluation of estrogen receptor in primary breast carcinoma by computer-assisted image analysis. Am J Clin Pathol 1988;90:233-9.

12. Koliopanos A, Friess H, di Mola FF, et al. Connective tissue growth factor gene expression alters tumor progression in esophageal cancer. World J Surg 2002;26:420-7.

13. Hartel M, Di Mola FF, Gardini A, et al. Desmoplastic reaction influences pancreatic cancer growth behavior. World J Surg 2004;28:818-25.

14. Xie D, Yin D, Wang HJ, et al. Levels of expression of CYR61 and CTGF are prognostic for tumor progression and survival of individuals with gliomas. Clin Cancer Res 2004; 10:2072-81.

15. Xie D, Nakachi K, Wang $\mathrm{H}$, et al. Elevated levels of connective tissue growth factor WISP-1, and CYR61 in primary breast cancers associated with more advanced features. Cancer Res 2001;61:8917-23.

16. Lin MT, Zuon CY, Chang CC, et al. Cyr61 induces gastric cancer cell motility/invasion via activation of the integrin/nuclear factor-kappaB/cyclooxygenase-2 signaling pathway. Clin Cancer Res 2005;11:5809-20.

17. Chang CC, Lin MT, Lin BR, et al. Effect of connective tissue growth factor on hypoxia-inducible factor 1alpha degradation and tumor angiogenesis. J Natl Cancer Inst 2006;98:984-95.

18. Gery S, Xie D, Yin D, et al. Ovarian carcinomas: CCN genes are aberrantly expressed and CCN1 promotes proliferation of these cells. Clin Cancer Res 2005; 11:7243-54.

19. Davies SR, Watkins G, Mansel RE, et al. Differential expression and prognostic implications of the CCN family members WISP-1, WISP-2, and WISP-3 in human breast cancer. Ann Surg Oncol 2007;14:1909-18.

20. Sakamoto S, Yokoyama M, Zhang $X$, et al. Increased expression of CYR61, an extracellular matrix signaling protein, in human benign prostatic hyperplasia and its regulation by lysophosphatidic acid. Endocrinology 2004;145:2929-40.

21. Chien W, Kumagai T, Miller CW, et al. Cyr61 suppresses growth of human endometrial cancer cells. J Biol Chem 2004;279:53087-96.

22. Wasenius VM, Hemmer $\mathrm{S}$, Kettunen $\mathrm{E}$, et al. Hepatocyte growth factor receptor, matrix metalloproteinase-11, tissue inhibitor of metalloproteinase-1, and fibronectin are up-regulated in papillary thyroid carcinoma: a cDNA and tissue microarray study. Clin Cancer Res 2003:9:68-75.

23. Tong $\mathbf{X}$, Xie $D, 0^{\prime} K e l l y ~ J$, et al. Cyr61, a member of CCN family, is a tumor suppressor in non-small cell lung cancer. J Biol Chem 2001;276:47709-14. 
24. Xie D, Miller CW, O'Kelly J, et al. Breast cancer. Cyr61 is overexpressed, estrogen-inducible, and associated with more advanced disease. J Biol Chem 2001;276:14187-94.

25. Hong $\mathbf{Y}, \mathrm{Ho} \mathrm{KS}$, Eu KW, et al. A susceptibility gene set for early onset colorectal cancer that integrates diverse signaling pathways: implication for tumorigenesis. Clin Cancer Res 2007:13:1107-14.

26. Rofstad EK. Microenvironment-induced cancer metastasis. Int J Radiat Biol 2000;76:589-605.
27. Kunz M, Moeller S, Koczan D, et al. Mechanisms of hypoxic gene regulation of angiogenesis factor Cyr61 in melanoma cells. J Biol Chem 2003;278:45651-60.

28. Lin BR, Chang CC, Che TF, et al. Connective tissue growth factor inhibits metastasis and acts as an independent prognostic marker in colorectal cancer. Gastroenterology 2005;128:9-23.

29. Rimon E, Chen B, Shanks AL, et al. Hypoxia in human trophoblasts stimulates the expression and secretion of connective tissue growth factor. Endocrinology 2008; 149:2952-8. 